\title{
II. Agenda, or a collection of observations and researches, the results of which may serve as the foundation for a theory of the earth
}

\section{De Saussure}

To cite this article: M. De Saussure (1799) II. Agenda, or a collection of observations and researches, the results of which may serve as the foundation for a theory of the earth , Philosophical Magazine Series 1, 5:19, 217-221, DOI: 10.1080/14786449908677143

To link to this article: http://dx.doi.org/10.1080/14786449908677143

曲 Published online: 18 May 2009.

Submit your article to this journal $\pi$

Џll Article views: 4

Q View related articles 5 
11. Agenda, or a Collection of Obfervations and Refearcbes, the Refults of wubich may firve as the Foundation for a Theory of the Eurtb. By M. DE SAussure.

[Concluded from Page 140.]

C H A P. XXIII.

Inffruments necefiry' for the Geolcgical Traveller.

i. THE moft neceffary inftrment is the miner's hammer. It will be requifite to have two, of different fizes: one fmall, to break fmall fragments of rolled pebbles, by holding them in the left hand while you ftike with the right. Its weight, including the handle, onght to be about ten ounces. The other muft be larger, to detach fragments of rock, and to break large pebbles: its weight ought to be quadruple that of tive fimall one. When I travel on horfeback, I have thefe two hammers fufpended from the bow of my faddle.

I. A. Two ftone-cutter's chifcls: one fmall, of from a line to a line and a half, to detach fniall cryftals, or other objects of fmall bulk; the other, feven or eight lines.

2. To try the hardncfs of foffils, a piece of ftcel to ftrike fire will be ncceffary; alfo a triangular file, pretty fine, and a ftrong bodkin of tempered ftecl.

3. Nitrous acid, with M. De Morvcau's boxes of reagents.

3. A. An artificial magnet, in a cife, with a fteel pivot on which it can be placed, to try the mignetifm of folfils.

4. A magnifying glafs of three inches focus, in order to enable the obferver to form a general itea of any foffil : another, of an inch focus, to examine its feparated parts ; and one of five or fix lines for clofer examination. Thefe three magnifiers muft be always in the traveller's pocket, or ready at hand: but, befides thefe, he mult have, for his clofet at home, a microfcope furniflied with a micrometer.

5. Telefcopes, to obferve inaeceffible mines and diffant mountains.

6. A pocket portfolio, with prepared paper for writing on, ros.V. If $\mathrm{f}$ 
with a pencil of tin folder, which it is not neceffary always to cut, and the writing of which is not fo eafily effaced as that of phumbago. In this portfolio the traveller mult write out; on the fpot, the fketch of his journal, and infert fuch obfervations as occur to him; but he muft take the trouble to tranfcribe thefe notes at more length, preferving the primitive notes, which will always retain a character of truth, and for that reafon people are fond of recurring to them.

7. Some quires of brown paper, a few theets of which may be carried in the pocket for wrapping up on the fpot fpecimens of the ftones you collect, the characters of which ought to be marked on the cover. You may afterwards pack them with hay into a bag deftined for that purpofe, until you have a fufficient quantity to form a box, which you may fend home by the public carriages wherever you find an oportuhity; but, as it is fatiguing for the traveller to load his pockets during the time of his excurfions, and as the guides often lofe them on purpofe in order to get rid of them, I have behind my faddle two leathern bags, into which I put them till I come to fome halting-place, where I have time to pack them with hay into a bag. M. Beffon recommends to thofe who undertake fea voyages to write with China ink the characters which ought to accompany minerals in long paftages. becaufe conmmon ink may be effaced by accidents.

8. A blow-prpe, with its apparatus. As "I make much ufe of this inftrument, which at length fatigues me, though I can blow with my cheeks without exercifing my breaft; I caufed to be conftructed a pair of portable double bellows, the fides of which contain each fixty-two fquare inches. Thefe bellows can be fufpended from the edge of a table; and $I$ put them in motion by preffing logether, between my knees, the two handles, which afterwards feparate by the action of the fpring. This apparatus may be eafily carried, and is very converient.

9. A graduated femicircle traced out on a copper-plate of a form exactly rectangular, with a plummet fufpended from the centre of the femicircle. This femicircle is the moft convenient inttrument for meafuring the inclination of ftrata, of veins and declivities; and it may always be carried in a pocket of the portfolio. 
10. A compars, furnithed with a crofs $\mathrm{ftaff}$, to find the direction of mountains, chains, vallies, and ftrata.

II. Portable barometers with two mercurial thermoneters; one affixed to a barometer to eflimate the temperature of the mercury in the latter, and the other with a bate butlb for meafuring the temperature of the air. Thofe who.fudy meteorology, as well as geology, ought to be furnifhed alfo with an hygrometer and an electrometer.

12. For afcertaining the temperature of the fea, at great depths, it will be neceffary to have a thermometer.conftructed like that defcribed in my Travels through the Alps*:' for lakes, an apparatus like that pointed out in the note of Section 1399, will be fufficient.

13. Thofe who underftand a litle geometry, ought to provide themfelves with a fextant, having an artificial horizon, and alfo a chain, in order that they may be able to meafure a bafe, and thus take the altitude of an inacceffible peak, the breadth of a river, \&c. \&cc. With this lextant they may alfo find the latitudes. In regard to the longitudes, they fequire, befides inftruments, an expertnefs in this kind of obfervation, which cannot be attained but by mariners or profeffed aftronomers.

14. It will be neceffary alfo to have within reach tools for repairing an inftrument in cafe it fhould happen to be deranged; fuch as pincers, files, turnfcrews, compaffes, gim. blets, wire, needles, thread, and packthread.

15. Laftly, fome good map, pafted on canvas, of the country you propofe to examine; and this map ought frequently to be compared with your itinerary, and the bearings given by your compafs.

i6. In regard to the care required for the traveller's perfon, he muft have a light drefs made of cloth, without lining, of a white colour, as well as his hat, that he may be lefs expofed to the heat of the fun's rays; with jackets, fome cool for the warm regions and the vallies, and the other warm for the cool regions and eminences; a good great coat; green fpectacles, and a black crape, to fecure the eyes and face from the fnow. Laftly, if he is to pafs the night in the open air, a

* Section 1392, Plate 1, fig. 3 . 
tent or cannonicre, a bear's 1kin to fleep upon, and woollen blankets.

17. A folid light walking-pole : mine for the high Alps is a young fir-plant, extremely dry, feven fect in length and 18 lines in diameter at the lower end, which is fhod with iron tapering to a ftrong point. Thefe dimenfions may appear large, but nothing can be too ftrong for the fteep rocks, glaciers, and fnow, when you are abliged to take your point of fupport at a diftance from you, and to reft the whole weight of your body on your pole, by holding it in a fituation very much inclined, and even horizontal, as may be feen in the Vignette to the Firft Volume of my Travels through the Alps. -For mountains which are not fo fieep, the traveller nay be fatisfied with poles of lefs ftrength and fize; but it will ftill be neceffary that they thould be four or five feet in height, and fufficiently ftrong that a perfon might be able to fupport himfelf with his two hands by holding them in a horizontal fituation, according to the attitude of the fmall figure which is on the left fide at top of the before-mentioned vignette; for, in traverfing or defcending a rapid decliyity, or in walking on the margin or edge of a precipice, the travelter muft always fupport himfelf by his two hand, holding the pole towards the mountain, and not towards the precipice, as thofe do who have not learned the art of travelling through mountains.

18. To prevent lipping on the hard fnow-ice, and grafsplats, which are ftill more clangerous, I would recommend iron cramps, fuch as thofe which I have caufed to be engraved in the third plate of the firf volume, and which I have long ufed with fuccels. In ny latt excurfions, liowever, I preferred thoes, the thick foles of which were armed with ftrong tacks, at the ditance of eight or nine lines from each other. The beads of thefe tacks are of fteel, and fhaped like a fquare pyramid: I have fome fnall ones, the points of which are only two lines and a half in height, and of about the fame breadth, for the fnow-rocks and grais-plats; and others, of double thefe dimenfions, for the hard fnow.

I9. In the latt place, with regard to provifions, when the traveller mutt refide for a conficerable time in the defarts, at a diftance from habitations, and even huts, he may carry 
with him fome falt or pickled meat; but M. Parmentier's faloop of potatoes, with cakes of portable foup, and bread, will form the moft nourifhing food, and what may be contained in the leaft room. A fmall iron chaffing-difh, a fmall bag filled with charcoal, and a pan of tinned copper or iron, form my kitchen apparatus for the mountains : wooden plates and fpoons may be found in the remoteft huts. It will be proper, however, to carry always in the pocket a cup of gum elaftic, in order that the traveller may at all times eafily quench his thirft, a want to which he will be frequently expofed in his excurfions.

From what has been faid, it may be readily feen, that the ftudy of geology will not fuit the indolent or fenfual; for the life of the geologue mut be divided between fatiguing and perilous journies, in which he is deprived of almaft all the conveniences of life, and the varied and deep refearches of the clofet. But what is ftill more rare, and perhaps more neceffary than the zeal requifite to furmount thefe obftacles, is, a mind free from prejudice, filled with an ardent defire for the truth alone, rather than with a defire for raifing or deftroying fyftems; capable of defcending to minute details indifpenfibly neceffary for the correctnefs and certainty of obfervations, and of rifing to grand views and general conceptions. Thofe fond of fuch ftudies, ought not, however, to be difcouraged by thefe difficulties; there is no traveller who may not make fome good obfervation, and bring with him at leaft one ftone worthy of being employed in the conftruction of this grand edifice. It is indeed poffible to be ufeful without attaining to perfection; for I have no doubt that if the mineralogical travels, even the maft efteemed, and much more thofe of the author, be compared with thefe Agenda, there will be found in them many deficiencies, and many obfervations, either imperfeet, or even totally forgotten: but I have mentioned the reafon in the Introduction. Befides, feveral of thefe ideas did not occur till I had finithed my travels; and for that reafon I laboured with more zeal on thefe Agenda, in the hope of rendering young perfons, on their entering this career, capable of performing what coft me thirty-fx years of travelling and ftudy. 